\title{
MULHERES NEGRAS NÃO FORAM FEITAS PARA CARREGAR LIVROS: TENSIONAMENTO E RESPOSTA SOCIAL EM REDE NA FEIRA PAN-AMAZÔNICA DO LIVRO NO PARÁ
}

\author{
Rosaly Brito ${ }^{1}$ \\ Universidade Federal do Pará \\ rosalysbrito@gmail.com \\ Lorena Esteves ${ }^{2}$ \\ Universidade Federal do Pará \\ estevesjornalismo@gmail.com \\ Jússia Ventura ${ }^{3}$ \\ Universidade Federal do Pará \\ jussiac@gmail.com
}

\begin{abstract}
Resumo
Este trabalho analisa a repercussão social do cartaz do "Salão do Livro da Região Sul e Sudeste do Pará", evento da Feira Pan-Amazônica do Livro de 2018, para compreender como o processo de resposta social, impôs uma mudança institucional por parte da Secretaria de Cultura do Estado. O país homenageado foi a Colômbia e a peça de divulgação destacava uma mulher negra carregando livros na cabeça, representação das palenqueras. $\mathrm{O}$ fato gerou repercussão nas redes sociais e na mídia local e nacional. Os protestos voltaram-se contra a reiteração de uma imagem que inferioriza as mulheres negras, reproduzindo colonialidades de gênero, poder e saber. O corpus compõe-se de postagens no Facebook e de matérias jornalísticas veiculadas em abril de 2018. Duas técnicas metodológicas foram usadas: a netnografia e a aplicação de um questionário online, por meio do Facebook e Whatsapp.
\end{abstract}

Palavras-chave: Feira Pan-Amazônica do Livro do Pará. Resposta Social. Ativismo Digital. Racismo Institucional. Colonialidade.

\section{BLACK WOMEN WERE NOT MADE TO CARRY BOOKS: TENSION AND SOCIAL RESPONSE IN NETWORK AT THE PAN-AMAZON BOOK FAIR IN PARÁ}

\begin{abstract}
This paper analyzes the social repercussion of the poster of the "Book Fair of the South and Southeast of Pará", an event of the Pan-Amazonian Book Fair of 2018, to understand how the social response process (BRAGA, 2006) imposed an institutional change. by the State Secretariat of Culture. The country honored was Colombia and the press release featured a black woman carrying books on her head, representing the palenqueras. The fact generated repercussions on social networks and local and national media. The protests turned against the reiteration of an image that inferiorizes black women, reproducing colonialities of gender, power and knowledge. The corpus consists of Facebook posts and news stories published in April 2018. Two methodological techniques were used: netnography (RECUERO, 2012; KOZINETS, 2014) and the application of an online questionnaire through Facebook and Whatsapp.
\end{abstract}

Keywords: Pan-Amazonian Book Fair of Pará. Social Response. Digital activism. Institutional Racism. Coloniality.

1 Professora da Faculdade de Comunicação e do Programa de Pós-graduação em Comunicação, Cultura e Amazônia, da Universidade Federal do Pará. Líder do grupo de pesquisa Comunicação, Política e Amazônia e membro do grupo de pesquisa Observatório de Comunicação, Culturas e Resistências na Pan-Amazônia.

${ }^{2}$ Doutoranda do Curso de Pós-Graduação Comunicação, Cultura e Amazônia, da Universidade Federal do Pará. Integrante do grupo de pesquisa Comunicação, Política e Amazônia e do grupo de pesquisa Observatório de Comunicação, Culturas e Resistências na Pan-Amazônia.

${ }^{3}$ Doutoranda do Curso de Pós-Graduação em Sociologia e Antropologia, da Universidade Federal do Pará e Professora do curso de Comunicação Social, da UFPA. Integrante do grupo de pesquisa Interações e Tecnologias na Amazônia e do grupo de pesquisa Comunicação, Consumo e Identidade.

Esta obra está licenciada sob uma Licença Creative Commons Atribuição 4.0 Internacional (CC BY-NC-AS 4.0). LOGEION: Filosofia da informação, Rio de Janeiro, v. 6 n. 1, p.106-125, set.2019/fev. 2020 


\section{INTRODUÇÃO}

O presente artigo busca analisar a repercussão social do cartaz do "Salão do Livro da Região Sul e Sudeste do Pará" no site da rede social Facebook em abril de 2018. O evento que ocorreu na cidade de Marabá, sudeste do Pará, em maio de 2018, foi organizado pelo Governo do Pará, por meio da Secretaria de Cultura do Estado e fez parte da programação da $22^{\mathrm{a}}$ Feira Pan-Amazônica do Livro.

O país homenageado pelo evento, em 2018, foi a Colômbia e a peça inicial de divulgação destacava a imagem de uma mulher negra carregando livros na cabeça, como representação das palenqueras - mulheres que usam roupas multicoloridas na Colômbia e andam com bacias de frutas em cima da cabeça. $\mathrm{O}$ fato gerou grande e rápida repercussão social, principalmente nas plataformas de divulgação online e, consequentemente, na mídia local e nacional. Os protestos voltaram-se contra a reiteração de uma imagem que inferioriza as mulheres negras, reforçando seu lugar social de trabalhadoras braçais, em detrimento do trabalho intelectual.

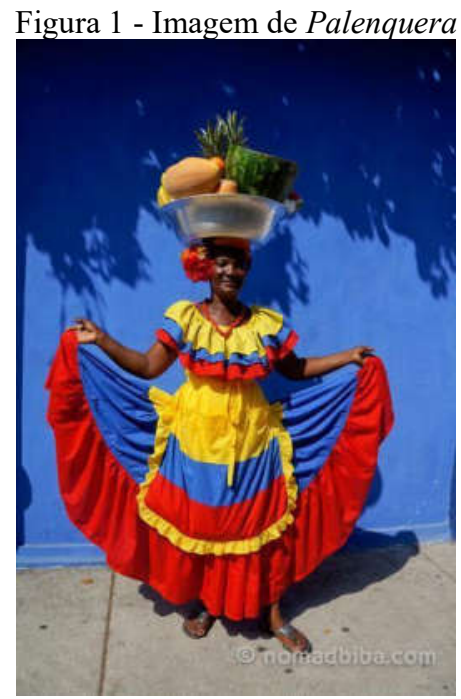

Fonte: nomadbiba.com
Figura 2 - Cartaz da Feira do Livro 2018

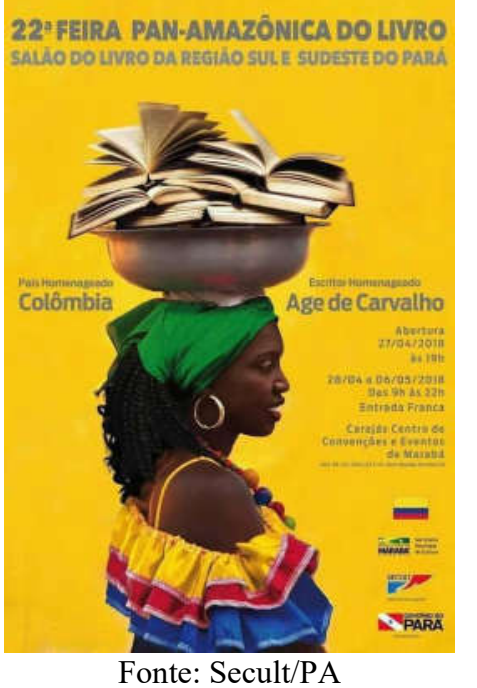

A programação da Feira também foi alvo de críticas pela ausência, inicialmente, de mulheres escritoras, negros e indígenas entre os convidados e homenageados. A onda de protestos, ocorrida primordialmente no ambiente digital, guarda traços de semelhança com a escala viral de repercussão nessas plataformas que outros movimentos sociais tiveram em rede, com campanhas que, inclusive e diferenciando-se do caso analisado aqui, tomaram as ruas (CASTELLS, 2017), como a "Primavera Árabe", em 2010; os protestos organizados por 
feministas, em 2015, que ficou conhecido como "Primavera Feminista"; a maior manifestação de mulheres do Brasil, conhecida como o movimento "\#EleNão", em 2018, e o "Tsunami da Educação", protagonizado por estudantes e professores, em 2019.

A tônica desses movimentos, inseridos na ordem da midiatização, é a atuação em rede, descentralizada, multidirecional, fragmentada, interativa, com ausência de estruturas organizacionais, enlaçamento de grupos identitários (WAINBERG, 2016; CASTRO, 2016; SANTINI, TERRA, ALMEIDA, 2016; CASTELLS, 2017), e inserida na esfera da circulação (BRAGA, 2006). Foi o caso observado na Feira Pan-Amazônica do Livro, com a onda de protestos contra o racismo institucional praticado por uma instância governamental que gerou uma série de mudanças na programação do evento.

Em resposta às acusações de racismo e machismo, a Secult alterou o cartaz trazendo uma imagem da escultura intitulada "Pensamento", produzida em 1992 pelo artista colombiano Fernando Botero. Além da imagem, o novo cartaz traz uma frase citando o escritor colombiano Gabriel García Márquez: "Para entender outra cultura, 'tudo é questão de despertar sua alma"'. Ficou evidente que a frase do novo cartaz, embora pudesse passar despercebida por quem não tomou conhecimento da polêmica, era uma resposta irônica da Secult à onda e críticas ao cartaz, que se viu obrigada a mudar a contragosto, buscando desqualificá-las.

A Feira Pan-Amazônica do Livro no Estado do Pará completou 23 anos em 2019. Atualmente, já é considerada a quarta maior feira literária do Brasil, movimentando milhões de reais e alcançando milhares de pessoas a cada edição ${ }^{4}$. Na edição de 2019, os organizadores do evento lhe deram o título de "Feira Pan-Amazônica do Livro e das Multivozes", homenageando duas personalidades de grande importância nos cenários literário, acadêmico e do ativismo social na região amazônica: o poeta João de Jesus Paes Loureiro e a professora e ativista Zélia Amador. Ele é poeta e pesquisador. Ela é pesquisadora e referência no movimento pelos direitos de negros e negras.

Parece-nos razoável supor que a proposta de tema e convidado(a)s homenageado(a)s da feira 2019, ao trazer como enunciado central a valorização de múltiplas vozes e identidades de gênero e raça ${ }^{5}$, em larga medida ainda pode ser tomada como desdobramento da polêmica instaurada na edição de 2018, com grande repercussão social, em forma de protestos, nas plataformas de divulgação online e na mídia local e nacional, em função da escolha da arte do

\footnotetext{
${ }^{4}$ G1 PA, disponível em: <https:/g1.globo.com/pa/para/noticia/2019/04/22/feira-do-livro-2019-vai-homenagearzelia-amador-de-deus-e-joao-de-jesus-paes-loureiro.ghtml>. Acesso em 12 jul 2019.

${ }^{5}$ Entendida aqui como uma construção social.
} 
cartaz e da programação, que demonstravam um viés claramente racista e sexista, refletindo um legado histórico de colonialidade, patriarcado e escravização.

O sistema de resposta social proposto por Braga (2006), que tomamos como referência conceitual para analisar o caso aqui estudado, é um sistema eminentemente processual, tendo em vista que as respostas ocorrem após uma relação de tensionamento entre dois setores. No caso do objeto desta pesquisa, essa relação de tensionamento ocorreu entre a sociedade civil e uma instituição governamental, que após a repercussão da informação no Facebook e no Whatsapp conquistou espaço nas pautas da mídia local e nacional. A circulação social, a partir da midiatização, para Braga (2006), permite que haja interação social, tendo em vista que a conversação acerca do objeto surge a partir do estímulo e dos dispositivos midiáticos. Desta maneira, surgiu a pergunta que norteia este artigo: Como se dá, na ordem da midiatização, o processo de resposta social, a ponto de provocar mudanças institucionais?

Para analisar o objeto empírico desta pesquisa, utilizaremos duas técnicas metodológicas: a netnografia (RECUERO, 2009; KOZINETS, 2014), e a aplicação de uma entrevista semiestruturada online. As técnicas foram selecionadas levando em consideração o objetivo deste trabalho. Dessa maneira, analisamos postagens compartilhadas no site da rede social Facebook, bem como matérias jornalísticas locais e nacionais que foram feitas a partir da mobilização social no período de 20 a 27 de abril de 2018, também vamos analisar as respostas ao questionário quantitativo aplicado online por meio do Facebook e WhatsApp.

\section{O SISTEMA DE RESPOSTA SOCIAL NA ORDEM DA MIDIATIZAÇÃO}

A intensa polêmica, objeto de análise deste artigo, que levou à mudança do cartaz da $22^{\mathrm{a}}$ Feira Pan-Amazônica do Livro, inscreve-se de maneira exemplar no ritmo e dinâmicas impostos pela ordem da midiatização. Esta ordem assinala uma transição de grande envergadura da sociedade dos meios para a sociedade midiatizada ou da midiatização (FAUSTO NETO, 2008). A primeira é a sociedade das mídias tradicionais, que dominaram o século XX, marcadas pela unidirecionalidade, verticalidade e pela suposição de um receptor passivo na outra ponta do processo. A segunda decorre da conformação de uma outra ecologia midiática, que emergiu especialmente após o advento das mídias digitais e da internet, promovendo deslocamentos fundamentais no entendimento da ordem comunicacional contemporânea.

A noção de cultura mediática ou de sociedade mediatizada, como destaca María Cristina Mata (1999), busca prover um novo princípio de compreensão sobre o fenômeno da produção coletiva de significados na sociedade atual, em vista da insuficiência das categorias 
anteriormente vigentes para dar conta de tais fenômenos. A autora se refere particularmente à noção de cultura massiva ou cultura de massas, que ao longo da maior parte do século passado buscou abarcar a discussão em torno da produção de bens culturais por parte dos sistemas industriais midiáticos destinados ao consumo de grandes massas da população.

O campo de investigação científica da comunicação constituiu-se, desde a primeira metade do século XX, em torno desse modelo eminentemente informacional, baseado na ideia da transmissão de significados controlada unilateralmente pelas corporações de mídia para receptores dispersos geograficamente. "Este modelo unidirecional é responsável pela crença no dualismo entre mídia e sociedade, dualismo que é tão mais danoso na medida em que ele é redobrado implicitamente pela polaridade entre ativo e passivo" (VAZ, 2006, p. 16). A mídia age e supostamente seus receptores sofrem seus efeitos passivamente, como assinala o autor. E mesmo com o deslocamento provocado pelas teorias da recepção, “o máximo a que se chega é atribuir uma capacidade de desvio de sentido no consumo a partir do pré-midiático na forma de crenças culturais funcionando como filtro, isto é [...] uma reação privada e pontual” (idem, p. 16).

Por outras palavras, a polaridade entre produção e recepção, que marcou decisivamente o modo de compreensão dos fenômenos midiáticos e da relação entre meios de comunicação e sociedade, relegou a uma zona de sombra a esfera da circulação, em que os sistemas de mídia e o público se tocam. Por muito tempo, essa esfera, portanto, se fez "invisível" ou "insondável", subsumida entre os dois polos acima referidos, vista como mero ponto de passagem de mensagens endereçadas pelo emissor ao receptor.

Com o redesenho da arquitetura midiática e o avanço crescente da midiatização, contudo, "a circulação institui novas formas de interações entre produtores e receptores de mensagens, complexificando seus papéis, ao organizá-los segundo novas dinâmicas de interfaces" (FAUSTO NETO, 2010, p. 55). A presença cada vez mais ativa do chamado terceiro polo, de acordo com o autor, institui novos objetos e passa a requerer procedimentos analíticos distintos, capazes de interpretá-los adequadamente.

A ênfase na circulação é um dos aspectos cruciais na sociedade da midiatização. Para além de um fenômeno circunscrito ao campo midiático, ela é bem mais ampla. Já não se trata, enfatiza Muniz Sodré, de uma sociedade que controla o discurso, "mas do discurso que controla retoricamente a sociedade como um todo, em tal escala que se constitui, ele próprio, numa esfera existencial particular" (2007, p. 20). A essa esfera ele dá o nome de bios midiático, em que se processa um tipo específico de interação, a "tecnointeração", responsável por um novo modo de presença do sujeito no mundo (SODRÉ, 2010, p. 24). 
Nesse sentido, José Luiz Braga (2012) ressalta que a circulação de significados na ordem da midiatização extrapola o objeto "meios", bem como o objeto "recepção", inscrevendo a ambos em formações muito mais complexas. Embora reconhecendo o peso das mudanças tecnológicas na configuração desse cenário, não é somente delas que a midiatização alimentase. Ao contrário, a seu ver, à invenção tecnológica deve-se acrescentar como componente fundamental a invenção social, ou seja, como a sociedade organiza as suas interações de modo a enfrentar a sua mídia.

Isso leva Braga a constatar que há um terceiro sistema de processos midiáticos que opera na sociedade, parte integrante e imprescindível da midiatização, que se materializa no que o autor nomeia de "sistema de resposta social", em que as relações, a despeito de serem informais, são histórica e socialmente fundadas.

\footnotetext{
O sistema de interação social sobre a mídia (seus processos e produtos) é um sistema de circulação diferida e difusa. Os sentidos midiaticamente produzidos chegam à sociedade e passam a circular nesta, entre pessoas, grupos e instituições, impregnando e parcialmente direcionando a cultura (BRAGA, 2006, p. 27).
}

Deve-se distinguir rigorosamente, no entanto, de outras perspectivas habituais, o sentido particular que a palavra circulação assume quando referida ao sistema de interação social sobre a mídia. Uma distinção fundamental, conforme o autor, diz respeito ao conceito material que se lhe atribui corriqueiramente, mais próximo da perspectiva econômica, de circulação de bens, em que importa primordialmente a relação entre oferta e consumo de bens e serviços. O que está em questão no sistema de interação social sobre a mídia não é o fato de um livro passar de mão em mão ou de que músicas circulem pela internet. "Importa que várias pessoas, tendo lido o mesmo livro ou ouvido e apreciado um mesmo tipo de música [...] "conversem" sobre tais objetos e interajam com base nesse estímulo" (BRAGA, 2006, p. 27-28).

A noção de sistema social, embora possa recobrir uma ampla variedade de caracterizações, de acordo com o autor, não se refere, neste caso, a um patamar concreto de instituições formais, ou mesmo a um agregado de pessoas, grupos, ideias e objetos. E sim, antes, a um "instrumento intelectual" capaz de nortear a percepção da realidade, "caracterizado pelo fato de fazer circular ideias, informações, reações e interpretações sobre a mídia e seus produtos e processos - de produzir respostas" (idem, p. 30). O sistema de resposta social, conceito por ele formulado, portanto, caracteriza-se por ser eminentemente processual entre setores da sociedade, por um lado, e ações e produtos da mídia, por outro. Essas relações são, ao mesmo tempo, de contiguidade e tensionamento. Neste artigo postulamos que foi esse tensionamento havido a partir do intenso debate social, travado especialmente por meio das redes sociais, mas com repercussões também na mídia tradicional, nesta esfera simbólica alargada que marca a 
atual ordem da midiatização, que produziu uma resposta institucional com a mudança do cartaz da Feira do Livro no Pará.

Em outro trabalho mais recente, o pesquisador destaca que na sociedade da midiatização há sempre um "fluxo adiante", que acontece de variadas formas, em que o sujeito tanto reposiciona o produto para outros usuários, modificado ou não, quanto elabora comentários, estimula debates, análises e polêmicas de caráter eminentemente agonístico, ou simplesmente repercute em uma mesa de bar ou nas demais formas de conversação cotidiana assuntos que estão em circulação. Em qualquer uma dessas formas está subentendida uma escuta prevista ou pretendida. Braga acredita ser esse fluxo contínuo e adiante, marcado pela retroação da resposta pretendida, um dos aspectos "mais pregnantes da midiatização" (2012, p. 41).

Nesses macroambientes de interação, de que as redes sociais fazem parte, há uma predominância da midiatização como processo interacional de referência. Torna-se cada vez mais difícil distinguir, aí, pontos iniciais ou pontos de chegada, produção e recepção como instâncias separadas. Por outro lado, não é de forma abstrata que esse processo ocorre, e sim por meio de circuitos culturais que são reconhecíveis pelos usuários (2012, p. 41-42). O caso aqui focalizado, conforme a discussão feita a seguir, parece-nos exemplar das rupturas havidas na ordem da midiatização, em que a esfera da circulação, antes obscurecida pela ênfase nos polos emissão/recepção, assume agora um lugar central. Redireciona e intensifica os "fluxos adiante", com alto grau de imprevisibilidade no desfecho dos processos, o que impõe às instituições que são confrontadas mudanças antes impensáveis.

\section{METODOLOGIA}

Para compreender como as interações dos usuários nas próprias redes sociais sobre a representação do cartaz ganharam forma e alcance a ponto de provocar uma mudança institucional, utilizamos como metodologia principal a netnografia. E, para verificar a hipótese de que foi por meio das redes sociais que a questão teve repercussão, aplicamos um questionário online, disponibilizado entre os dias nove e quatorze de junho de 2018. Para comprovar o alcance nacional também trazemos matérias jornalísticas locais e nacionais que foram publicadas a partir da mobilização social no período de 20 a 27 de abril de 2018 .

O questionário foi produzido na plataforma de criação de questionários e pesquisas online da Google, o Google Forms e possuía 4 questões: 1. Você soube da mudança do cartaz da Feira Pan-amazônica do livro deste ano (2018), e da polêmica que gerou?; 2. Se sim, de que forma você ficou sabendo?; 3. No caso de ter sabido da polêmica, você acha que a imagem da 
mulher na $1^{\text {a }}$ versão do cartaz era preconceituosa?; e 4. Como acha que essa mulher foi representada? Após o fim da aplicação do questionário, obtivemos 88 respostas, que contribuíram para a análise netnográfica.

A netnografia foi adaptada da etnografia das Ciências Sociais para o ambiente online e permite ao pesquisador fazer o trabalho de observação a partir da inserção em comunidades, desta maneira, tendo contato intra-subjetivo com o objeto de estudo (AMARAL; NATAL; VIANA, 2017). Para Braga (2007), e Recuero (2012), a netnografia também considera as práticas de consumo midiático e leva em consideração "os processos de sociabilidade e os fenômenos comunicacionais que envolvem as representações do homem dentro de comunidades virtuais" (AMARAL; NATAL; VIANA, 2017, p. 35).

$\mathrm{Na}$ área da comunicação, além da netnografia, a pesquisa demanda a aproximação com outras técnicas como análises quantitativas e estatísticas (questionários), Análise de Redes Sociais e Análise de Conteúdo (AMARAL; NATAL; VIANA, 2017). Nesta pesquisa, embora tenha sido feita uma análise do conteúdo postado pelos usuários a partir da netnografia, não tivemos a pretensão do uso estrito da metodologia de Análise de Conteúdo.

Para Kozinets (2014), a análise de dados contempla o processo de transformar os produtos coletados durante a observação em pesquisa, com arquivos de texto, gráficos, capturas de tela, transcrição de entrevistas online e notas do pesquisador. Durante a coleta e análise de dados, o pesquisador pode usar várias ferramentas de mecanismo de busca.

Para chegar ao corpus, utilizamos o buscador do próprio site do Facebook. As palavraschave para essa busca foram: cartaz e feira panamazônica do livro, que levaram a um total de 155 postagens públicas, sendo 85 delas com alusão à polêmica do cartaz. As outras postagens faziam referência a outras 21 edições da Feira Pan-Amazônica do Livro e feiras literárias que ocorrem pelo Brasil. Buscamos uma análise inicial qualitativa, entre as postagens selecionadas.

Desta maneira, para compor o nosso corpus, foram escolhidas as duas postagens mais populares (Ver Quadros 2 e 3), levando em consideração o maior número de curtidas, comentários e compartilhamentos durante o período de 18 a 27 de abril de 2018, que serão analisadas a seguir. Ressalta-se que, embora limitada, a amostra é adequada para a análise, tendo em vista que o objetivo, aqui, é estudar o conteúdo de forma exemplificativa, sem generalizar.

As matérias, artigos de opinião e notas, coletadas para esta pesquisa, foram encontradas pelo sistema de busca do Google, por meio das palavras-chave: cartaz feira do livro Pará 2018 e mudança cartaz feira do livro Pará. Após a busca, foram selecionadas 11 publicações que também compõem o corpus de análise desta pesquisa. 
Figura 3 - Postagem 1 e Interações

\section{Post 1}

\section{Interações}

63 Paloma Franca Amorim

Pöem uma mulher negra com livros na cabeça no. cartaz e não tem uma mulher negra na programaçăo principal da feira pan amazônica do fivro. Não vou ficar calada, não.

A feira pan amaźnica do livro quer mulheres pretas pra carregarem na cabeça os livros dos sinhozinhos, porque na programaçăo mesmo da feira não tem uma mulher preta, amazônida, fazendo mesa ou fala.

Aplausos pro racismo institucional do dia, dessa vez no meu estado, o Pará, na feira onde cresci e me fiz leitora.

Estou enojada

Secult - Secretaria de Estado de Cultura do Pará

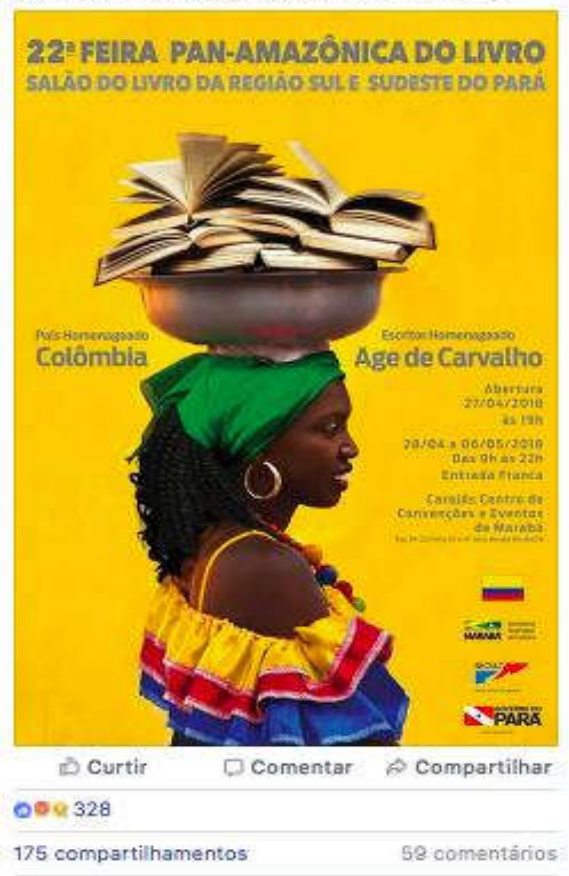

(2)

Não tem UM DIA. A cara de pau dessa gente.. Curtir - Responder - 8 sem

6 coronelismo intelectual. Estou é enojada oportunismo de Curtir - Responder - 8 sem $\operatorname{CS} 2$

9. Escreva uma resposta... ()ㅜㅇㅇㅇ (다요

(B) Sem falar no estereótipo. (1) Curtir-Responder - 8 sern

6) $\mathrm{sim}$. Uma visualidade fácil de mulher preta, um discurso previsivel e que ainda a afasta da relação com os livros.

Curtir - Responder - $B$ sem

(6) Sempre a subserviência. $O_{2}$ Curtir - Responder - 8 sem
a Escreva uma resposta.

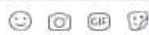

8

Xá eu ver se eu entendi: será que mulher negra não tem capacidade intelectual de escrever e só serve para carregar os livros publicados por gente branca? Curtir - Responder - 8 sern

(3) Cara, eu tô muito puta! Curtir-Responder 8 sem $D$ ?

9. Escreva uma resposta...

(9) tanta coisa errada que não sei nem o que dizer, só sentindo muita raiva mesmo, pqp! Curtir-Responder - 8 sem

(8) .. É todo dia um tapa na nossa cara... Pra cada uma conquista/alegria nossa, 50 chibatadas... Curtir-Responder - 8 sem

Diga-se de passagem, os livros estão como um peso para a mulher do cartaz... Misericórdia. Curtir - Responder - 8 sem

Fonte: Dados da pesquisa 
Figura 4 - Post 2

(4.) 25 de abril $\cdot 0$
NOTA DE REPÚDIO AO CARTAZ MACHISTA E RACISTA DA XXII FEIRA 2 novas fotos. PAN-AMAZONNICA DO LIVRO

(Obs - a primeira imagem foi criticada sendo substituida pela segunda. Que apresenta critica aos que nåo aceitaram a primeira.)

Diante da polêmica gerada pelo cartaz da XXII Feira Pan-Amazônica do Livro, que, na tentativa de representar a diversidade da cultura colombiana, acabou por reproduzir a lógica da colonialidade que subalterniza a mulher negra latino-americana, nós do Grupo de Estudo e Pesquisa Eneida de Morais (GEPEM), da Universidade Federal do Pará, nos somamos às diversas reaçరెes críticas feitas a esse cartaz e apresentamos nossa nota de repúdio ao machismo e racismo presentes na imagem.

O cartaz apresenta uma mulher negra carregando uma bacia de livros na cabeça. Segundo os organizadores, uma forma de dar visibilidade às mulheres palenqueras de Cartagena, na Colômbia, pais homenageado nesta ediçăo da Feira. As palenqueras de Cartagena săo mulheres que estăo por todo o centro histórico da cidade vendendo frutas em suas bacias e que chamam a atenção dos turistas pelo colorido de suas roupas, simpatia e formosura. Mais do que isto, são mulheres que carregam uma história de luta das mulheres negras contra a escravidão, o colonialismo, o racismo e o patriarcado. Herdeiras dos povos cimarrones, conquistaram a liberdade ao se refugiarem nos palenques (equivalentes aos quilombos no Brasil) e construiram uma história de vida marcada pela resistência e luta. O acesso à educação, à leitura e à produçăo do conhecimento tem sido historicamente negado às mulheres negras, e assim também ocorreu com as palenqueras. Estas mulheres têm sido duplamente oprimidas - por serem mulheres e por serem negras. E uma das formas utilizadas pelo colonialismo e pela colonialidade para oprimir estas mulheres é a negação do seu direito de ler e escrever. Apesa disto, essas mulheres têm resistido e se lançado à ousada tarefa de ler, registrar e interpretar o mundo com sua própria perspectiva, o que é uma afronta à sociedade machista e racista que as subjugou ao longo dos séculos.

O referido cartaz relaciona-se com essa história de sujeição e luta, ao retratar a mulher negra colombiana e latino-americana como alguém que simplesmente carrega livros, mas não os elabora e escreve. Dess modo, reproduz um imaginário patriarcal e racista, que năo valoriza a mulher como produtora do conhecimento.
Ao expressar nossa indignaçăo, conclamamos para que os organizadores da XXII Feira Pan-Amazőnica do Livro possam refletir sobre as imagens que publicam, especialmente as referentes as mulheres e năo simplesmente ignorar o debate substituindo por outra imagem, pois, o enfrentamento acontece na reestruturação de pensamento e na forma de ler uma imagem. Importante destaca inclusive, na programaçăo, o engajamento das mulheres colombianas como protagonistas dos debates e reflexöes. (Ad̛riane Lima, coordenadora da Linha de Pesquisa Gênero, Feminismo e Interseccionalidade/ GEPEM/UFPA)

Belém, 23 de abril de 2018

Grupo de Estudo e Pesquisa Eneida de Morais (GEPEM/UFPA) Linha de Pesquisa Gênero, Feminismo e interseccionalidade

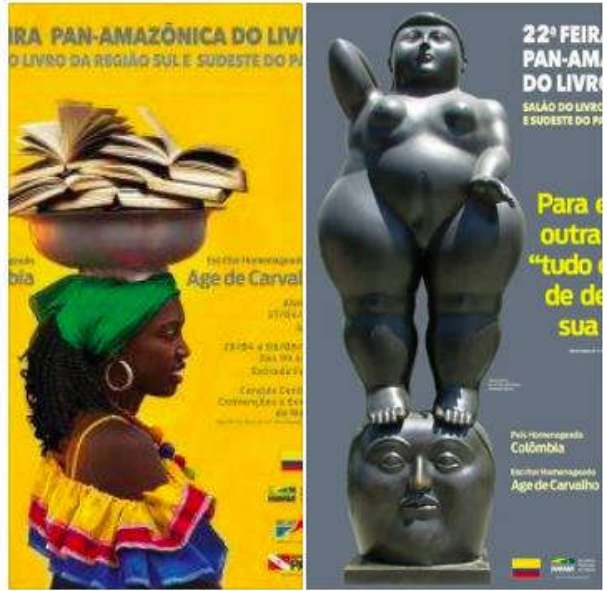

13 Curtir

$\square$ Comentar

$\phi$ Compartilhar

(19) Manuela Corral, Gabriela Sobral e outras 189 pessoas

105 compartilhamentos 52 comentários

Fonte: Dados da pesquisa.

Figura 5 - Interações ao Post 2

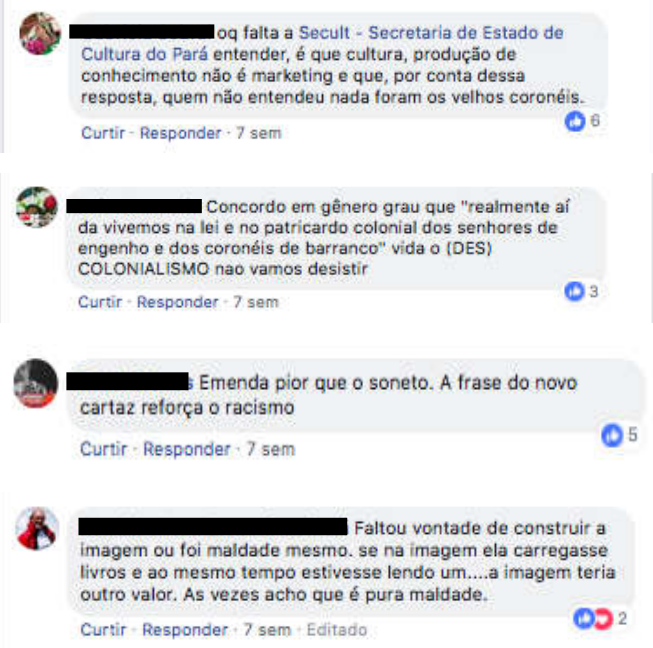

(3) Vale lembrar que não há autoras negras ou indígenas na programação principal da Feira em Gelém. A crítica ao cartaz é a porta de entrada para o aprofundamento da discussão sobre os significados dessa Feira falida, de coronéis e sinhás, na região Amazônica. Uma região preponderantemente negra e indigena. Curtir - Responder - 7 sem - Editado

Ninguém, ninguém precisa meis machista e esnobe. Š̃o os mesmos intesta infutifera a cos princípios seculares de continuarem achando que o burro tá na sombra.

Curtir - Responder - 7 sem

(-7) Bela fala e bela posiçăo do GEPEM. A luta é também semiótica. Curtir-Responder - 7 sem 


\section{ANÁLISE}

As postagens encontradas durante a busca tratam, em sua totalidade, sobre a polêmica do cartaz da Feira do Livro. Do total de 85 postagens disponíveis para pesquisa, ou seja, que aparecem públicas, $100 \%$ fazem críticas ao cartaz, sendo que $90 \%$ se referem ao assunto alertando para o machismo e cerca de $80 \%$, além da misoginia, fazem menção a racismo, tendo em vista que a mulher retratada no cartaz é negra. Os dados vão ao encontro dos obtidos pelo questionário online, já que em ambos a maioria das manifestações ressalta o preconceito. Das 88 pessoas que responderam, $60 \%$ consideravam o cartaz preconceituoso, $31 \%$ acharam que não e $9 \%$ não sabiam responder (Gráfico 1).

Gráfico 1 - Respostas à pergunta 3 do questionário online
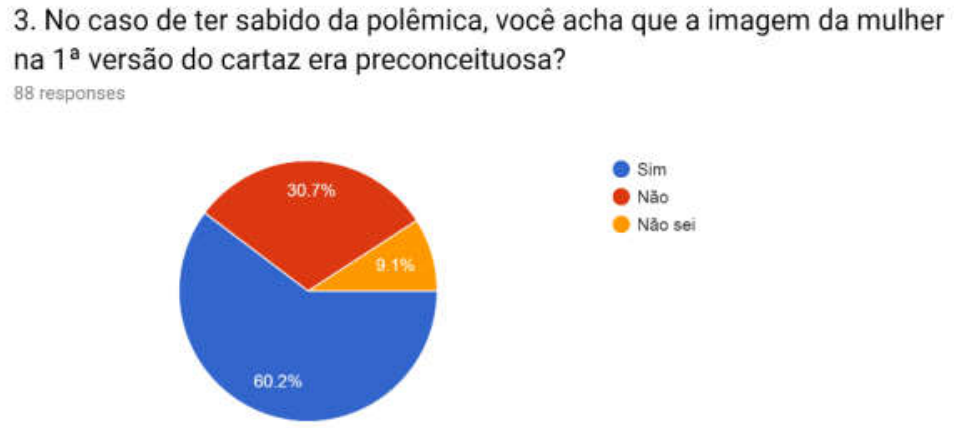

Fonte: Dados da pesquisa, via Questionário Google Forms.

A primeira versão do cartaz divulgado pela Secult, como já citado, destacava a imagem de uma mulher negra carregando livros na cabeça, como representação das palenqueras mulheres que usam roupas multicoloridas na Colômbia e carregam bacias de frutas em cima da cabeça. No entanto, a imagem claramente inferioriza as mulheres negras, reforçando um imaginário social que as subalterniza e as coloca em condição de trabalhadoras braçais, e não como leitoras de livros ou plenamente aptas ao trabalho intelectual. O cartaz promove uma dupla operação de sentido: em primeiro lugar, reitera a função social atribuída aos corpos negros desde a escravização e, ao mesmo tempo, naturaliza uma vez mais a divisão sexual do trabalho historicamente imposta às mulheres (GONZALEZ, 1983; CARNEIRO, 2003; AMADOR DE DEUS, 2012; DAVIS, 2016, BIROLI, 2016).

A crítica ao estereótipo reafirmado pelo cartaz da Feira ganhou corpo nas redes sociais, principalmente no Facebook. O fato gerador sobre o cartaz alcançou visibilidade por meio da divulgação da postagem da escritora Paloma Amorim na rede social Facebook, esta que foi a 
principal fonte de propagação da informação, como reiterado na nossa pesquisa online, na qual $43 \%$ das pessoas afirmaram que ficaram sabendo do fato pelo Facebook; $23 \%$ pelo WhatsApp; $12 \%$ por portais de notícias e o restante tomou conhecimento pelo Twitter, televisão, jornal, amigos e universidade (Gráfico 2).

Gráfico 2 - Respostas a pergunta 2 do questionário online

\section{Se sim, de que forma você ficou sabendo?} 88 responses
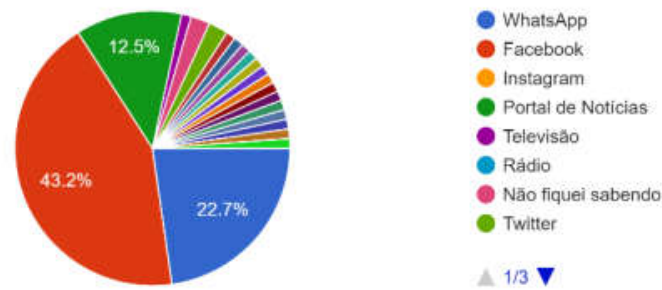

Fonte: Dados da pesquisa, via questionário Google Forms.

Escritora paraense, feminista e negra, nesta postagem ela chama atenção para o discurso construído pela organização do evento, a partir da imagem de uma mulher negra carregando livros em uma bacia. A postagem foi compartilhada 175 vezes, curtida por mais de 300 perfis e comentada 59 vezes, até o momento da coleta desta pesquisa. Para a escritora, o cartaz é portavoz do evento que "quer mulheres pretas para carregarem os livros dos sinhozinhos porque na programação mesmo da feira não tem uma mulher preta, amazônida fazendo mesa ou fala" (AMORIM, 2018).

As interações na postagem feita por Paloma criticam a escolha da representação, como nos exemplos a seguir.

Figura 6 - Exemplos de interações ao Post 1

Exemplo 1:

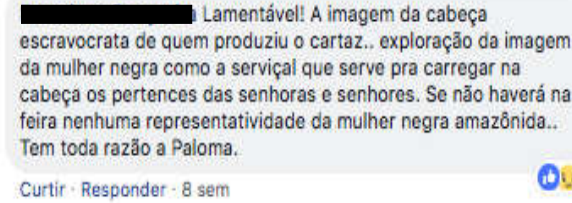

Fonte: Dados da pesquisa.

\section{Exemplo 2:}

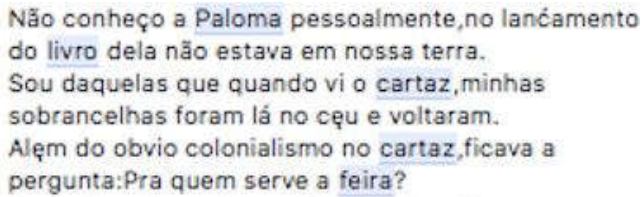

As críticas presentes na fala de Paloma e nos comentários ao post dela vão de encontro a um discurso marcadamente colonial, eurocêntrico, universalista e hegemônico que constrói 
uma visão sexista e racista sobre o papel das mulheres negras na sociedade contemporânea (GONZALEZ, 1984; CARNEIRO, 2003; LUGONES, 2014; DAVIS, 2016). Especialmente, as mulheres pertencentes ao eixo do Sul Global (entre estas, as da Amazônia), inseridas em um território geopolítico atravessado por assimetrias e desigualdades, além de um contexto histórico por si marcado por violências, opressões e formas de resistência (AMADOR DE DEUS, 2012; CONRADO, CAMPELO, RIBEIRO, 2015; CASTRO, 2017; ARAGÓN, 2018).

Outra postagem amplamente comentada e compartilhada no Facebook refere-se à nota de repúdio do Gepem, que ganhou status de notícia ao ser divulgada no Portal Gepem Acontece e veiculada em outros portais jornalísticos. O Gepem é o Grupo de Estudos e Pesquisas sobre Mulher e Gênero "Eneida de Moraes", da UFPA, referência nos estudos e debates sobre gênero. A nota reitera que as mulheres negras, assim como as palenqueras, tiveram acesso à educação, à leitura e à produção do conhecimento historicamente negado, destacando que essas mulheres têm sido duplamente oprimidas - por serem mulheres e por serem negras (GEPEM, 2018). A nota ainda enfatiza que o cartaz retrata a mulher negra colombiana e latino-americana "como alguém que simplesmente carrega livros, mas não os elabora e escreve”. Desse modo, reproduz uma colonialidade de gênero, de poder e do saber (LUGONES, 2008, 2014; MIGNOLO, 2005; LANDER, 2005), que reforça uma divisão global do trabalho, em favor de um imperialismo intelectual exercido pelos grandes centros de produção do Norte Global, que sempre se atribuiu o poder de validar um conhecimento tido como universal, porém, que invisibiliza, silencia e desconsidera as experiências coloniais do Sul Global, em especial as das mulheres da Amazônia, que assumem particularidades em suas complexidades históricas, formas de resistência, subjetividade, agenciamento e opressão (BALLESTRIN, 2017; CONRADO, CAMPELO, RIBEIRO, 2015).

Vários usuários do Facebook que tiveram acesso à nota divulgada pelo GEPEM reagiram corroborando o discurso feito pelo grupo.

Figura 7 - Exemplos de interações ao Post 2

Exemplo 1:

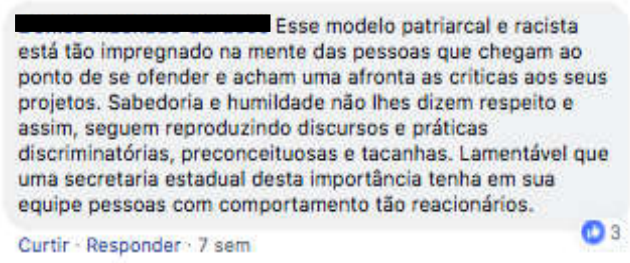

Fonte: Dados da pesquisa.
Exemplo 2:

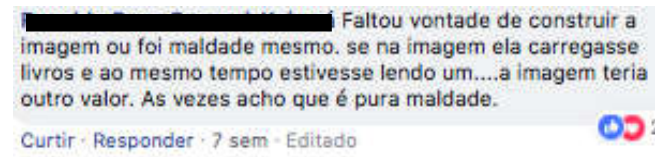

Curtir - Responder $7 \mathrm{sem}$ - Editado 
Os comentários aos Posts ( 1 e 2) vão ao encontro do que os participantes da pesquisa online responderam no questionário aplicado, mais da metade (54\%) acreditam que a mulher está sendo representada como trabalhadora braçal; 16\% acreditam, porém, que a mulher está sendo representada no cartaz como leitora. Outros comentaram que é a representação de uma "escrava", "submissa", "servente", "como apenas mais uma escrava, que não tinha acesso ao conhecimento", "escrava servindo livros ao seu 'dono"”.

Essa representação remete a séculos de opressão e subalternidade, nos quais a mulher esteve condicionada por sua condição biológica, com diferenças abismais entre as mulheres brancas e negras (DEL PRIORE, 2011). Segundo Davis (2016), “o ponto de partida de qualquer exploração da vida das mulheres negras na escravidão seria uma avaliação de seu papel como trabalhadoras" (p. 17). Para a autora, esse enorme espaço que o trabalho ocupa, hoje, na vida das mulheres negras reproduz um padrão estabelecido durante a escravização, já que, como escravas, essas mulheres tinham todos os outros aspectos de sua existência ofuscados pelo trabalho compulsório.

Após a rápida viralização nas redes sociais, a questão virou notícia e alcançou repercussão no jornalismo local, sendo veiculada em blogs e sites, além dos principais portais de notícias do estado, como G1 (do grupo Globo) e DOL (Do Grupo RBA). Mas também obteve alcance nacional, como o Portal de notícias da Folha de São Paulo e o Portal UOL, por meio do blog Bidê, da jornalista Luka Franca, no qual ela assinala que "a polêmica em torno do evento tomou corpo, um corpo e visibilidade nacional que não me lembro de ter visto antes envolvendo a Feira" (FRANCA, 2018).

De um universo de 11 publicações, entre matérias, artigos de opinião e notas, coletadas para esta pesquisa, nove abordaram a questão do racismo institucional praticado pela Secult e as revoltas que o fato gerou, principalmente nas redes sociais. "A programação da Feira também foi alvo de reclamações pela falta de mulheres escritoras, negros e indígenas entre os convidados e homenageados" (GRUPO GLOBO, 2018). As matérias enfocaram especialmente a polêmica em torno da imagem veiculada no cartaz. "A imagem fez com que algumas pessoas acusassem a organização do evento de reproduzir o racismo e o machismo" (DOL, 2018).

É sabido que o povo negro sofreu séculos sob o jugo de um sistema escravagista que o via como propriedade e as mulheres eram vistas como unidades de trabalho lucrativas. De acordo com Davis (2016), no que dizia respeito ao trabalho, a produtividade era mantida "sob a ameaça do açoite" (p. 19). Mesmo após o fim da escravidão e toda a luta e resistência do povo negro para garantir a ampliação de seus direitos, ainda permanece, no Brasil, "um padrão cultural sexista, racista e etnocêntrico" que exclui as mulheres negras até mesmo das mais 
recentes conquistas das mulheres brasileiras (BASTHI, 2011, p. 20). Nesse caso, a ausência de escritoras negras como convidadas em uma Feira que ocorre na Amazônia, um território cujo tecido social é formado marcadamente pela presença de negros e indígenas, é um exemplo claro dessa exclusão.

Esse fato remete a uma outra questão levantada por posts e algumas matérias e artigos em blogs, coletados na pesquisa, a falta de bibliodiversidade em uma Feira realizada na Amazônia. Um exemplo é o artigo de Haroldo Ceravolo Sereza (2018), publicado na coluna Opinião do Portal PublishNews. Segundo Sereza, a bibliodiversidade é um conceito que surgiu no Chile em meados dos anos 2000 e coloca em questão a visibilidade de diferentes projetos editoriais no mercado, permitindo vê-los para além "dos projetos dominantes". A importância da bibliodiversidade, a seu ver, reside no fato de que as políticas públicas, a regulação do mercado livreiro, as compras governamentais, os eventos e as coberturas jornalísticas "evitem que o poder do dinheiro, dos preconceitos, da ideologia e do capital simbólico sejam os critérios quase que únicos nessas escolhas”.

Diante da visibilidade que o caso alcançou, a Secult emitiu uma nota, divulgada nas redes sociais, em que a questão iniciou e tomou maiores proporções, e defendeu que jamais foi o intuito causar uma interpretação equivocada sobre a representação da mulher negra e afirmou que encontrou outra forma de referência, "mantendo a justa e devida menção à Colômbia, país homenageado nesta edição e lamenta que a referida imagem tenha causado leituras diferentes do que pretendíamos, o que jamais foi o intuito, conforme devidamente esclarecido" (SECULT, 2018).

Ao reiterar na nota que não havia a intenção de causar uma interpretação equivocada, a Secult demonstra que a reiteração de estereótipos e a invisibilização de vozes e discursos de grupos considerados politicamente minoritários estão naturalizadas pelo imaginário coletivo e são reproduzidas nas práticas profissionais. Os estereótipos, portanto, não contribuem para representar a pluralidade e diversidade formada pelo tecido social, especialmente no caso desta pesquisa, do âmbito da Amazônia paraense. Ao contrário, essas distorções contribuem para o reforço a uma posição de desigualdade e subordinação das mulheres e fortalecem a visão normativa e excludente das identidades sexuais nas sociedades.

\section{CONSIDERAÇÕES FINAIS}

Há séculos a mulher precisa lutar para conquistar a ampliação de seus direitos fundamentais, entre eles, o direito ao trabalho, a escolha da profissão e de ser valorizada e 
reconhecida por suas competências e conquistas, independente, da condição biológica que possui. No entanto, apesar da ampliação de direitos da mulher em vários âmbitos sociais, ainda persiste no imaginário coletivo uma visão colonial, patriarcal, machista, sexista e etnocêntrica. Uma das consequências disso é uma divisão sexual do trabalho que desvaloriza, segrega e não garante equidade de direitos a homens e mulheres em suas inserções no mercado, nesse caso, no mercado editorial literário, e a situação agrava-se, especialmente, quando nos referimos às mulheres negras e amazônidas.

Parece-nos evidente que o caso em análise aqui, como discutido na abertura deste artigo, inscreve-se exemplarmente nos processos de midiatização acima descritos. Apresenta, inclusive, uma singularidade que merece ser destacada. $\mathrm{O}$ fato gerador, a denúncia e o protesto contra os sentidos veiculados no cartaz da Feira Pan-Amazônica do Livro, acusado de ser "racista e misógino", nasce na rede social Facebook e logo transita para o WhatsApp, para só depois, em vista da grande repercussão alcançada, virar pauta da imprensa nacional.

Assume, inequivocamente, a dinâmica do "fluxo adiante" e as características de um sistema de resposta social, reunindo mais e mais adeptos que o reverberam em escala viral, em circuitos culturais que se reconhecem e se identificam com o cerne da denúncia e querem fazer ecoar sua indignação com outras formas de exclusão também presentes na feira, como o fato de não terem sido contemplados inicialmente na programação negros, indígenas e outros segmentos sociais de grande importância e representatividade no cenário amazônico. A repercussão nas redes e na imprensa impôs um recuo público à Secretaria de Cultura do Pará, que se viu obrigada, ainda que a contragosto como sugere a nota que divulgou, a mudar o cartaz da feira e a fazer alterações de última hora na programação de maneira a contemplar minimamente o que fora reivindicado.

A decisão de incluir no enunciado central do tema da Feira do Livro a ideia das multivozes e homenagear uma escritora mulher e ativista do movimento negro na edição de 2019 sugere que a onda de protestos desencadeada na edição anterior do evento e a intensa repercussão que teve impôs, em alguma medida, uma revisão da postura institucional. Muito embora as colonialidades de poder, do saber, de gênero e raça sejam persistentes e entranhadas nas práticas institucionais, o episódio aqui analisado nos incita a pensar que há algo novo na ordem da midiatização, ou no que Castells chamou de "autocomunicação de massa", que permite abrir brechas e impor fraturas nas bases das colonialidades instituídas. 


\section{REFERENCIAS}

AMADOR DE DEUS, Zélia. Espaços africanizados do Brasil: algumas referências de resistências, sobrevivências e reinvenções. Revista Eletrônica: Tempo-Técnica-Território, Brasília, v. 3, n. 2, p. 059-071, 2013.

AMARAL, Adriana; NATAL, Geórgia; VIANA, Lucina. Netnografia como aporte metodológico da pesquisa em comunicação digital. Cadernos da Escola de Comunicação, Curitiba, v. 1, n. 6, 2017.

ARAGÓN, Luis Eduardo. A dimensão internacional da Amazônia: um aporte para sua interpretação. Revista Nera, São Paulo, n. 42, p. 14-33, 2018.

BALLESTRIN, Luciana Maria. Feminismos subalternos. Estudos Feministas, Florianópolis, v. 25, n. 3, p. 1035-1054, 2017.

BASTHI, Angélica (org). Guia para Jornalistas sobre Gênero, Raça e Etnia. Brasília: ONU Mulheres; Federação Nacional dos Jornalistas (FENAJ); Programa Interagencial de Promoção da Igualdade de Gênero, Raça e Etnia, 2011. (Fundo de Alcance dos Objetivos do Milênio, F-ODM).

BIROLI, Flávia. Divisão sexual do trabalho e democracia. Revista Dados de Ciências Sociais, Rio de janeiro, v. 59, n. 3, p. 719-754, 2016.

BRAGA, José Luiz. A sociedade enfrenta sua mídia: dispositivos sociais de crítica midiática. Paulus, 2006.

BRAGA, José Luiz. A sociedade enfrenta sua mídia: dispositivos sociais de crítica midiática. Prefácio de Paulo Vaz. São Paulo: Editora Paulus, 2006, p. 13-18.

BRAGA, José Luiz. Circuitos versus campos sociais. In: MATTOS, Maria Ângela; JANOTTI

BRASIL. Constituição da República Federativa do Brasil de 1988. Disponível em:

http://www.planalto.gov.br/ccivil_03/constituicao/constituicao.htm. Acesso em: 03 Jun 2018.

BRASIL. Decreto-Lei. n. ${ }^{\circ}$ 5.452, de $1^{\circ}$ de maio de 1943, aprova a Consolidação das Leis do Trabalho. Disponível em: http://www.planalto.gov.br/ccivil03/decreto-lei/Del5452.htm. Acesso em: 03 Jun 2018.

CARAJÁS O JORNAL. Organizador do Salão do Livro diz que escritora paraense não conhece a Região Norte. Publicado em: 26 Abr 2018. Disponível em:

https://correiodecarajas.com.br/entretenimento/organizador-do-salao-do-livro-diz-queescritora-paraense-nao-conhece-a-regiao-norte/. Acesso em: 12 Mai 2018. 
CARNEIRO, Sueli. Enegrecer o feminismo: a situação da mulher negra na América Latina a partir de uma perspectiva de gênero. Racismos contemporâneos. Rio de Janeiro, v. 49, p. 49$58,2003$.

CASTELLS, Manuel. Redes de indignação e esperança: movimentos sociais na era da internet. Zahar, 2017.

CASTRO, Edna. Territórios em transformação na Amazônia: saberes, rupturas e resistências. Belém: NAEA, 2017.

CAVALLINI, Marta. Mulheres ganham menos que os homens em todos os cargos e áreas, diz pesquisa. G1: Economia. Publicado em: 07 mar. 2018. Atualizado em: 07 mar. 2018. Disponível em: https://g1.globo.com/economia/concursos-e-emprego/noticia/mulheresganham-menos-que-os-homens-em-todos-os-cargos-e-areas-diz-pesquisa.ghtml. Acesso em: 02 Jun 2018.

CONRADO, Mônica; CAMPELO, Marilu; RIBEIRO, Alan. Metáforas da cor: morenidade e territórios da negritude nas construções de identidades negras na Amazônia paraense. AfroÁsia, Salvador, n. 52, p. 213-246, 2015.

DAVIS, Angela. Mulheres, raça e classe. Tradução Heci Regina Candiani. São Paulo: Boitempo, 2016.

DEL PRIORE, Mary (org). História das mulheres no Brasil. Coordenadora de textos Carla Bassanezi Pinsky. 10. ed. São Paulo: Contexto, 2011.

DOL. Diário Online. Secult muda cartaz de Feira do Livro após acusação de racismo e machismo. Publicado em: 25 Abr 2018. Disponível em: http://m.diarioonline.com.br/noticias/para/noticia-503614-secult-muda-cartaz-de-feira-dolivro-apos-acusacao-de-racismo-e-machismo.html. Acesso em: 12 Mai 2018.

FAUSTO NETO, Antonio. As bordas da circulação. Alceu, Rio de Janeiro, v. 10, n. 20, p. 55-69, jan-jun 2010.

FAUSTO NETO, Antonio. Fragmentos de uma «analítica» da midiatização. Matrizes, São Paulo, v. 1, n. 2, p. 89-105, 2008.

FLÁVIO PINTO, Lúcio. Cartaz muda. E a feira do livro?. Publicado em 25 Abr 2018. Disponível em: https://lucioflaviopinto.wordpress.com/2018/04/25/cartaz-muda-e-a-feira-dolivro/. Acesso em: 12 Mai 2018.

FRANCA, Luka. Exclusão racista e machista marcam XXII Feira Pan Amazônica do Livro. Opera Mundi/Blog Bidê/UOL. Publicado em: 20 Abr 2018. Disponível em: http://operamundi.uol.com.br/blog/samuel/bide/exclusao-racista-e-machista-marcam-xxiifeira-pan-amazonica-do-livro/. Acesso em 12 Mai 2018. 
FRANCA, Luka. Feira Pan Amazônica do Livro: Organizadores apenas reafirmam racismo e machismo ao responder denúncias. Opera Mundi/Blog Bidê/UOL. Publicado em: 02 Mai 2018. Disponível em: http://operamundi.uol.com.br/blog/samuel/bide/racismo-feira-panamazonica-paloma/. Acesso em 28 Mai 2018.

GELEDÉS. Instituto da Mulher Negra. Secretaria de Cultura do Pará altera cartaz de Feira do Livro após polêmicas envolvendo racismo. Disponível em:

https://www.geledes.org.br/secretaria-de-cultura-do-para-altera-cartaz-de-feira-do-livro-apospolemicas-envolvendo-racismo/. Acesso em: 12 Mai 2018.

GEPEM ACONTECE. Nota de repúdio ao cartaz machista e racista da XXII Feira PanAmazônica do livro. Publicado em: 24 Abr 2018. Disponível em: http://gepemacontece.blogspot.com/2018/04/nota-de-repudio-ao-cartaz-machista-e_24.html. Acesso em: 12 Mai 2018.

GONZALEZ, Lélia. Racismo e sexismo na cultura brasileira. Revista Ciências Sociais Hoje, São Paulo, v. 2, n. 1, p. 223-244, 1983.

GRUPO GLOBO. Feira do Livro 2019 vai homenagear Zélia Amador de Deus e João de Jesus Paes Loureiro. G1: Pará. Publicado em 22 abr. 2019. Disponível em: https://g1.globo.com/pa/para/noticia/2019/04/22/feira-do-livro-2019-vai-homenagear-zeliaamador-de-deus-e-joao-de-jesus-paes-loureiro.ghtml. Acesso em 12 jul 2019.

GRUPO GLOBO. Secretaria de Cultura do Pará altera cartaz de Feira do Livro após polêmicas envolvendo racismo. Publicado em: 25 Abr 2018. Atualizado em: 26 Abr 2018. Disponível em: https://g1.globo.com/pa/para/noticia/secretaria-de-cultura-do-para-alteracartaz-de-feira-do-livro-apos-polemicas-envolvendo-racismo.ghtml. Acesso em: 12 Mai 2018.

JUNIOR, Jeder; JACKS, Nilda (org). Mediação \& midiatização: livro Compós 2012. Salvador: EDUFBA; Brasília: Compós. p. 32-53.

KOZINETS, Robert. Netnografia: realizando pesquisa etnográfica online. Porto Alegre: Penso, 2014.

LANDER, Edgardo (org). A colonialidade do saber: eurocentrismo e ciências sociais. Perspectivas latino-americanas. Ciudad AutÛnoma de Buenos Aires: CLACSO, 2005. (ColecciÛn Sur Sur, CLACSO).

LOPES, Cristiane Maria Sbalqueiro. Direito do trabalho da mulher: da proteção à promoção. Cadernos Pagu, Campinas, v. 26, n. 1, p. 405-430, 2006.

LUGONES, María. Coloniality and gender. Tabula rasa, Colombia, n. 9, p. 73-102, 2008.

LUGONES, María. Rumo a um feminismo descolonial. Revista Estudos Feministas, Florianópolis, v. 22, n. 3, p. 935-952, 2014.

\section{Matérias analisadas}


MATTA, Maria Cristina. De la cultura masiva a la cultura mediática. Diálogos de la comunicación, Colombia, n. 56, 1999.

MATTOS, Maria Ângela; JANOTTI JR, Jeder; JACKS, Nilda (org.) Mediação \& midiatização: livro Compós 2012. Salvador: EDUFBA; Brasília: Compós, 2012.

MENON, Isabella. Após queixas sobre racismo, Secretaria da Cultura do Pará muda cartaz de feira. Folha de São Paulo. Publicada em: 25 Abr 2018. Disponível em:

https://www1.folha.uol.com.br/ilustrada/2018/04/apos-queixas-sobre-racismo-secretaria-dacultura-do-para-muda-cartaz-de-feira.shtml. Acesso em: 12 Mai 2018.

MIGNOLO, Walter D. A colonialidade de cabo a rabo: o hemisfério ocidental no horizonte conceitual da modernidade. In: LANDER, Edgardo (org). A colonialidade do saber: eurocentrismo e ciências sociais. Buenos Aires: Clacso, p. 33-49, 2005.

RECUERO, Raquel. Jogos e práticas sociais no Facebook: um estudo de caso do Mafia Wars. In: ANDRADE, Luiz Adolfo; FALCÃO, Thiago. Realidade Sintética: Jogos Eletrônicos, Comunicação e Experiência Social. São Paulo: Scortecci, 2012.

SANTINI, Rose Marie; TERRA, Camyla; DE ALMEIDA, Alda Rosana Duarte. Feminismo 2.0: a mobilização das mulheres no brasil contra o assédio sexual através das mídias sociais (\# primeiroassedio). P2P e Inovação, Rio de Janeiro, v. 3, n. 1, p. 148-164, 2016.

SEREZA, Haroldo Ceravolo. O piloto automático das feiras de livros (e da imprensa). Publishnews. Publicado em: 23 Abr 2018. Disponível em: http://www.publishnews.com.br/materias/2018/04/23/o-piloto-automatico-das-feiras-delivros-e-da-imprensa. Acesso em: 12 Mai 2018.

SODRÉ, Muniz. Antropológica do espelho. Petrópolis: Vozes, 2010.

SODRÉ, Muniz. Eticidade, campo comunicacional e midiatização. In: MORAES, Denis. Sociedade midiatizada. Mauad, Rio de Janeiro, 2006.

SODRÉ, Muniz. Sobre a episteme comunicacional. MATRIZes. Revista do programa de PósGraduação em Ciências da Comunicação, São Paulo, n.1, São Paulo, p. 15-26, outubro de 2007.

SRZD. Secretaria da Cultura do Pará muda cartaz de feira considerado racista. Publicado em: 25 Abr 2018. Disponível em: http://www.srzd.com/brasil/secretaria-dacultura-do-para-cartaz-racista/. Acesso em: 12 Mai 2018.

WAINBERG, Jacques. As redes e os protestos sociais: A difusão da mensagem dissidente. Reinvenção comunicacional da política: Modos de habitar e desabitar o século XXI. Brasília: Compós, 2016. 